\title{
The Development of an Android-Based Anggah- Ungguhing Balinese Language Dictionary
}

\author{
https://doi.org/10.3991/ijim.v12i1.7105 \\ I Made Agus Wirawan( $\left.{ }^{(}\right)$, Ida Bagus Made Ludy Paryatna \\ Universitas Pendidikan Ganesha, Bali, Indonesia \\ imade.aguswirawan@undiksha.ac.id
}

\begin{abstract}
Indonesia is an archipelago country with a variety of local languages; one of which is Balinese (mother tongue), used by the Balinese people in daily life and in certain ritual ceremonies. In Universitas Pendidikan Ganesha, Department of Balinese Language Education, students have been given Anggah-Ungguhing in speaking subjects where they are taught to understand the use of Balinese language based on social strata. But in the process of learning the Anggah-Ungguhing, there are some problems, including: 1) There is no media that supports learning of Anggah-Ungguhing vocabulary. 2) The motivation of students when learning Anggah-Ungguhing by using books is low. Based upon the analysis on the problems and previous researches, this study aims to: 1) Development of mobile dictionary to support the learning process Angggah - Ungguhing anywhere and anytime. 2) Measuring the level of student's motivation are using mobile dictionary while learning vocabulary Anggah - Ungguhing. The method used in this research is Software Development Life Cycle (SDLC) with Waterfall based model. Based on the results of tests that have been done, mobile dictionaries can be declared successfully developed based on user needs. In this research has distributed about 60 questionnaires to measure the level of student's motivation who use mobile dictionaries on learning Anggah - Ungguhing Balinese language. The result of the student's motivation measurement shows that the motivation of the students that the learns Anggah - Ungguhing Balinese languange using mobile dictionary is in the positive category.
\end{abstract}

Keywords-Mobile Learning, Mobile Dictionary, Anggah - Ungguhing, Balinese languages, Mother Tongue, Android, Waterfall Model, Student Response.

\section{Introduction}

Indonesia is an archipelago country with various regional languages; one of which is Balinese language that, as a mother tongue, is used for everyone particularly among Balinese people in daily life or in a ritual ceremony. UNESCO in $21^{\text {st }}$ February has defined the importance to protect and preserve Balinese language ("ajeg Bali") as the mother tongue and as the World Mother Tongue Day since 1999 [1, 2].

Department of Balinese Language Education, one of the existing Language and Art Faculties in Universitas Pendidikan Ganesha, indirectly has become a parameter for 
the process of coaching, developing and preserving Balinese language. Through the material of Anggah-Ungguhing Balinese language in speaking subject, the students are taught about the word structure and the sentence level to understand the communication of Balinese language both in the class and in social life with any social strata.

From the observation result, the researcher also working as the lecturer in speaking subject has identified a number of problems in the learning process including:

1. There is no media that supports learning of Anggah-Ungguhing Balinese language. Currently the learning process Anggah - Ungguhing Balinese language is only based on books provided by the lecturer. This resulted in a lack of interest of students to learn Anggah - Ungguhing Balinese language outside the classroom.

2. The motivation of students when learning Anggah-Ungguhing Balinese language by using books is low.

Along with the advance of technology of communication and information a learning process is possible to be conducted not only in the classroom but also in anywhere and anytime. It is highly influenced by the technology development - particularly mobile technology $[3,4,5,6]$.

A number of researches have been successfully conducted regarding the mobilebased learning development for the local language dictionary such as the Androidbased application developed for Sundanese language [7], the development of the android-based application of Indonesia-English dictionary and the one for Nias [8]. Other studies were also conducted by [9] to develop the application of Balinese- Indonesian language dictionary. However, this research did not use any level of Anggah-Ungguhing Balinese language.

Based upon the analysis on the problems and previous researches, it has been found the importance of the development of the android-based application of Balinese language dictionary to facilitate the rapid and practical learning process of AnggahUngguhing Balinese language at Department of Balinese Language Education without requiring any books.

\section{$2 \quad$ Literature Review}

This research used a number of literature reviews related to the educational aspect and mobile technology including: M-Learning; Anggah-Ungguhing Balinese Language.

\subsection{Balinese Language Level (Anggah-Ungguhing Balinese Language)}

Balinese language is one of regional languages in Indonesia and has been well maintained by its speakers, in this case Balinese people. It is a mother tongue or main language for most of Balinese people and used as a communication tool in any social activities. Hence, it becomes a support for the sustainability and development of Balinese cultures. Regarding the number of native speakers, Balinese language is 
spoken by around half million people and becomes a tradition of literature of Balinese language. Historically, there are three periods in Balinese language:

1. Kuna Balinese Language (ancient). It is Balinese language used as a communication media in the ancient era of Balinese kings and it is the invention of the inscription of ancient Bali in the form of papyrus containing some letters or ancient Javanese language.

2. Tengahan Balinese language. It is a language used to write the Balinese literary works such as Kidung, Babad, Wariga, Usada, Usana, or Niti.

3. Kepara Balinese Language (Common Language). It is Balinese language still used as the communication media in today daily life or to interact with other people.

In recent period, Balinese language, regarding its users, has a language levelling system called as Sor - Singgih Balinese language. In its usage, Sor - Singgih Balinese language, as stated in Indonesian Language dictionary issued by Basic Education Agency of Bali Province, is defined as low, smooth or respectful language. In other words, Sor-Singgih Balinese language deals with the rules of high or low level about feeling that refers to solidarity by respect through Balinese language to other people. The division of phase in accordance to Sor-Singgih Balinese Language consists of:

1. Basa Kasar, Kasar Pisan/Kasar Jabag

2. Basa Andap

3. Basa Madia

4. Basa Alus, Alus Sor, Alus Mider, and Alus Singgih

5. Basa Mider.

Table 1. The level of Anggah-Ungguhing Balinese language

\begin{tabular}{|c|c|c|c|}
\hline \multicolumn{4}{|c|}{ Anggah-Ungguhing Balinese Language } \\
\hline No & $\begin{array}{c}\text { Word level (Rasa Basa Kruna } \\
\text { Basa Bali) }\end{array}$ & $\begin{array}{c}\text { Sentence level (Rasa Basa } \\
\text { Lengkara Basa Bali) }\end{array}$ & $\begin{array}{c}\text { Paragraph level (Rasa } \\
\text { Basa, Basa Bali) }\end{array}$ \\
\hline 1. & kruna alus singgih & lengkara alus singgih & Basaalus \\
\hline 2. & kruna alus madia & lengkara alus madia & Basamadia \\
\hline 3. & kruna alus sor & lengkara alus sor & Basaandap \\
\hline 4. & kruna alus mider & lengkara andap & Basakasar \\
\hline 5. & kruna mider & lengkara kasar & \\
\hline 6. & kruna andap & & \\
\hline 7. & kruna kasar & & \\
\hline
\end{tabular}

Balinese language has a levelling system. The first person talking about the Balinese language levelling as written in documentation is J. de Vroom (1872), a Dutch using a term called "Masor Singgih". The Balinese language level is also known as "Anggah-Ungguhing" [10, 11, and 12] 


\section{$2.2 \quad$ M-Learning Theory}

Mobile learning or m-learning is mostly referred to e-learning. In its first definition, m-learning refers to learning using cellular technology from e-learning [13]. It is globally introduced as a flexible learning approach and as a learning process delivered through a wireless mobile phone enabling a learning to be conducted flexibly in time and place. M-learning is used for the learning process of individual and community in an isolated area in the social and geographical perspective [14].

There is no any specific definition of mobile learning but many definitions have been developed purposely to identify it. Quinn [15] defined m-learning as a mobile device-based e-learning such as Palms, machine of Windows CE, even digital cellular phone". Mobile learning is also viewed as "the exploitation of hand hardware in everywhere, wireless network and cellular phone to improve and extend the scope of learning process" [16]. A study in 2004 conducted by Naismith et al. [17] suggested that mobile technology could be connected with six types of learning or categories of activity: behaviourist, constructivist, situated, collaborative, informal/lifelong, and support/coordination. Jones et al. [18], by contrast, considered the motivational or affective aspects of mobile learning as the defining characteristics, namely control (over goals), ownership, fun, communication, learning-in-context and continuity between contexts. The works of Winters [19] concluded that the perspective in mobile learning today commonly consists of four categories:

1. Techno-centric: mobile learning is primarily seen as a learning supported by mobile devices

2. An extension of e-learning: mobile learning is a subset of e-learning

3. Augmenting formal education: mobile learning complements the formal education

4. Learner-centred: mobile learning is about mobility and context

The mobile devices are not only limited to the communication devices, but also as a tool for the students in accessing knowledge anywhere and anytime. More educational institutions worldwide move to mobile learning as a way to enhance the education quality. The potential of mobile learning applied in education is able to contribute a significant benefit in terms of cost effectiveness, comfort, learning motivation, accessibility, and flexibility, closeness of information and interaction [13,14, 15, and 16]. As a part of e-learning, m-learning automatically is a part of distance learning (dlearning). 


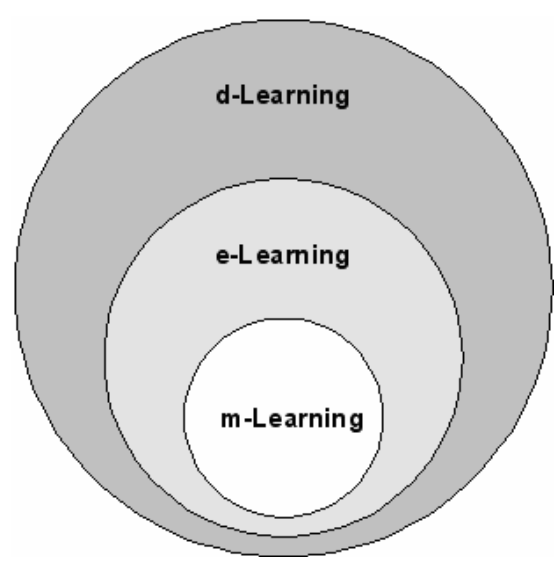

Fig. 1. Perspective of learning paradigms [5]

\section{$3 \quad$ Methodology}

\subsection{Research setting and procedures}

This research used Waterfall Model method. The research roadmap using the waterfall model is presented Table 2 .

\subsection{Variable}

The independent variable in this research was the android-based application of Balinese language dictionary; while the dependent one measured in this research was the response of the students in Department of Balinese Language Education using the dictionary application as the supplement in the learning process of Anggah Ungguhing Balinese language in speaking subject.

\subsection{Research Sample/Subject}

Sample/subject in this research was the students of Department of Balinese Language Education taking speaking subject in the second semester in the academic year of $2014 / 2015$.

\subsection{Sampling Technique}

In the second semester of the academic year of 2014/2015, the number of students randomly taken was 30 students ( 1 class) that had a smart phone (android). 
Table 2. The research roadmap

\begin{tabular}{|c|c|c|c|}
\hline Phase & Activities & Location & Deliverable \\
\hline Analysis & $\begin{array}{l}\text { 1) Analysis on the learning } \\
\text { process of Anggah- } \\
\text { Ungguhing Balinese lan- } \\
\text { guage in speaking subject } \\
\text { 2) Literature study in Journal } \\
\text { and Existing System } \\
\text { 3) Data collection for the } \\
\text { glossaries of Anggah- } \\
\text { Ungguhing Balinese lan- } \\
\text { guage from a number of dic- } \\
\text { tionaries and lecture materi- } \\
\text { als. } \\
\text { 4) Analysis on the flow of } \\
\text { procedure in management } \\
\text { system to be developed. }\end{array}$ & $\begin{array}{l}\text { 1) Classroom of } \\
\text { Department of } \\
\text { Balinese Lan- } \\
\text { guage Education } \\
\text { 2) LCI } \\
\text { 3) LCI } \\
\text { 4) LCI }\end{array}$ & $\begin{array}{l}\text { 1) The problems in the learning } \\
\text { process of Anggah-Ungguhing Ba- } \\
\text { linese language in speaking subject } \\
\text { were identified } \\
\text { 2) The theories of Anggah-Ungguhing } \\
\text { Balinese language, Mobile learning } \\
\text { and some theories from relevant } \\
\text { researches were described. } \\
\text { 3) The glossaries about Anggah- } \\
\text { Ungguhing Balinese language from } \\
\text { some sources were collected. } \\
\text { 4) The entity/user of system and } \\
\text { characteristics of the users were } \\
\text { described. }\end{array}$ \\
\hline Design & $\begin{array}{l}\text { 1) The design of the system } \\
\text { architecture } \\
\text { 2) The design of the interface } \\
\text { system } \\
\text { 3) Design of ERD }\end{array}$ & $\begin{array}{l}\text { 1) LCI } \\
\text { 2) LCI } \\
\text { 3) LCI }\end{array}$ & $\begin{array}{l}\text { 1) An android-based leaning system } \\
\text { design to the dictionary of Anggah- } \\
\text { Ungguhing Balinese language } \\
\text { 2) Mobile and web-based interface } \\
\text { design for the dictionary of Ang- } \\
\text { gah-Ungguhing Balinese language. } \\
\text { 3) The database and relational design }\end{array}$ \\
\hline $\begin{array}{l}\text { Develop- } \\
\text { ment }\end{array}$ & $\begin{array}{l}\text { 1) Database Implementation } \\
\text { 2) Interface System Implemen- } \\
\text { tation } \\
\text { 3) System implementation to } \\
\text { the server } \\
\text { 4) Collecting data to the lexi- } \\
\text { cons of Anggah-Ungguhing } \\
\text { Balinese language }\end{array}$ & $\begin{array}{l}\text { 1) LCI } \\
\text { 2) LCI } \\
\text { 3) LCI } \\
\text { 4) Department of } \\
\text { Balinese Lan- } \\
\text { guage Education }\end{array}$ & $\begin{array}{l}\text { 1) Database was implemented } \\
\text { 2) Interface System implementation } \\
\text { 3) System has been applied in server } \\
\text { and ready in use. } \\
\text { 4) The data of lexicons of Anggah- } \\
\text { Ungguhing Balinese language were } \\
\text { collected. }\end{array}$ \\
\hline Testing & $\begin{array}{l}\text { 1) Unit testing } \\
\text { 2) Integration testing } \\
\text { 3) System testing } \\
\text { 4) User acceptance testing }\end{array}$ & $\begin{array}{l}\text { 1) LCI } \\
\text { 2) LCI } \\
\text { 3) LCI } \\
\text { 4) LCI and class- } \\
\text { room in Depart- } \\
\text { ment of Balinese } \\
\text { Language Educa- } \\
\text { tion }\end{array}$ & $\begin{array}{l}\text { 1) Each function/class has been } \\
\text { verified in accordance with the al- } \\
\text { gorithm flow } \\
\text { 2) The integration of function/class } \\
\text { has been verified in accordance to } \\
\text { the algorithm of flow class } \\
\text { 3) The system entity has been verified } \\
\text { in accordance with the algorithm } \\
\text { flow } \\
\text { 4) The system entity has been validat- } \\
\text { ed in accordance with the users' } \\
\text { needs. }\end{array}$ \\
\hline $\begin{array}{l}\text { Further } \\
\text { Testing }\end{array}$ & $\begin{array}{l}\text { 1) Field test to the students of } \\
\text { Department of Balinese Lan- } \\
\text { guage Education } \\
\text { 2) Field test to the lecturers of } \\
\text { speaking subject }\end{array}$ & $\begin{array}{l}\text { 1) Classroom in } \\
\text { Department of } \\
\text { Balinese Lan- } \\
\text { guage Education } \\
\text { 2) Classroom in } \\
\text { Department of } \\
\text { Balinese Lan- } \\
\text { guage Education }\end{array}$ & $\begin{array}{l}\text { 1) Percentage of response from the } \\
\text { students (users) of Department of } \\
\text { Balinese Language Education } \\
\text { 2) Percentage of response from the } \\
\text { lecturers (users) of speaking sub- } \\
\text { ject in Department of Balinese } \\
\text { Language Education. }\end{array}$ \\
\hline \multicolumn{4}{|c|}{ Maintenance Phase was not done in this research } \\
\hline
\end{tabular}




\subsection{Data Analysis}

The responses of the students were descriptively analysed using the questionnaires by means of Likert Scale 5 (score 1 to 5). The conversion of the response of the students can be seen in Table 3.

Table 3. Likert Scale [20]

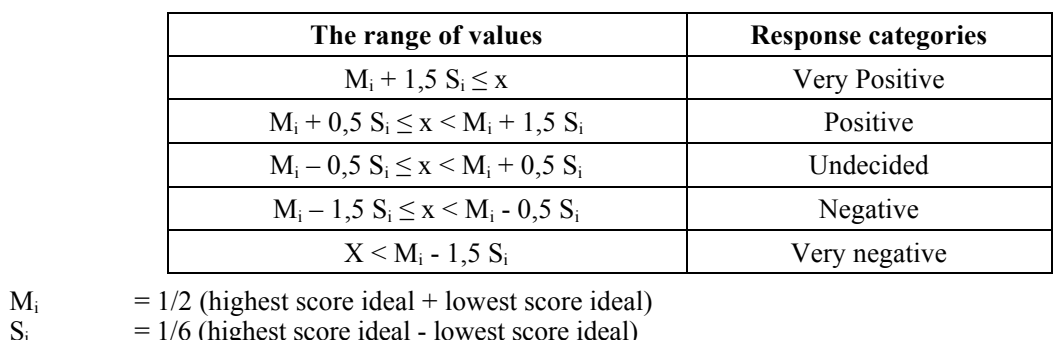

\subsection{Research Achievement Criteria}

The development and the use of android-based dictionary of Anggah-Ungguhing Balinese language have facilitated the students in learning the vocabularies of Anggah-Ungguhing Balinese language in Department of Balinese Language Education. It would be successful if this application could fulfil the criteria of this research including: (1) the application of android-based dictionary of Anggah - Ungguhing Balinese language has been successfully developed and 2) the response of students using this application was in the category of positive or above.

\section{Results and Discussion}

This research developed the android-based application of Anggah-Ungguhing Balinese language in speaking subject. This research was conducted for eight months from March to October 2015. The development of this application consisted of mobile application and web application. The development of mobile application used android, and the web application was developed using PHP.

\subsection{System Architecture}

Based upon the analysis on the characteristics of students in learning the AnggahUngguhing Balinese language and other needs, the system architecture can be designed as shown in Figure 2. 


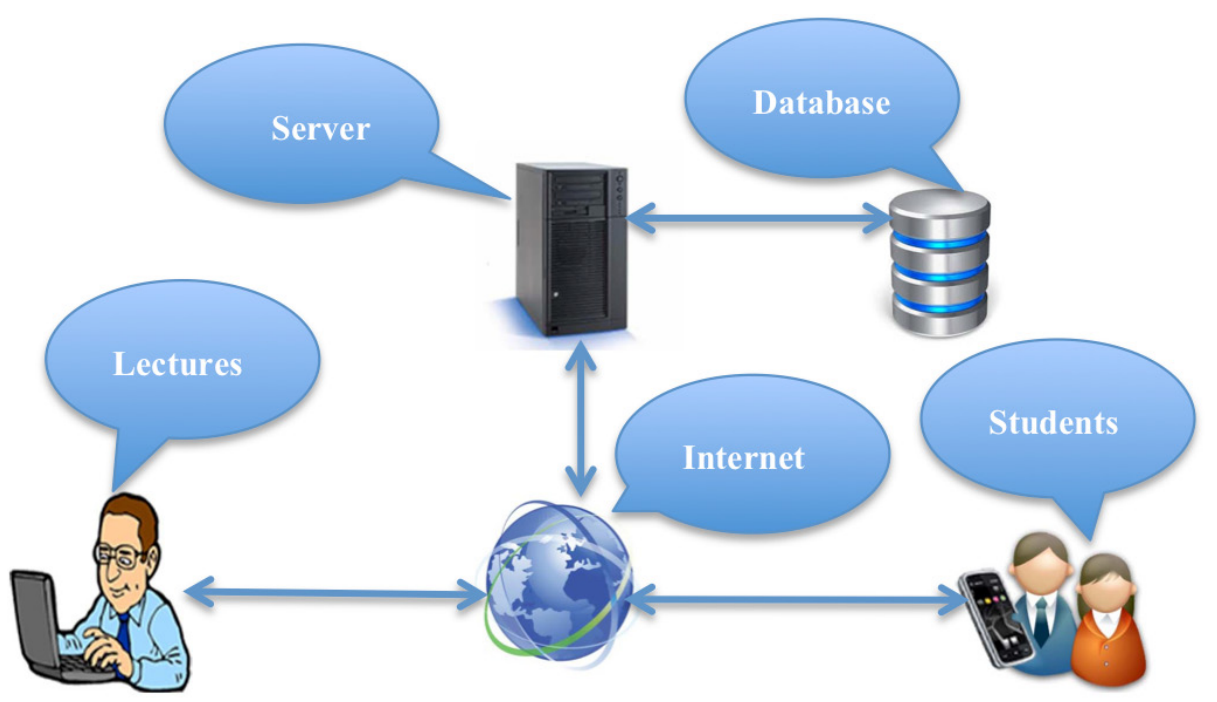

Fig. 2. Architecture design

Based on the system architecture, there were two entities that can access this system entity among students in accessing the android-based application and the entity of lectures accessing the web application and as administration. All data (vocabularies) would be saved in database server. This application development using MySQL database. The programming language used for lecturers' application is PHP while the students' application uses the android.

\subsection{Mobile-based dictionary application}

Mobile based application was used by the users (students) to translate the words from the Anggah--Uugguhing Balinese language into Indonesian Language or vice versa. There have been some processes that have been reached in this research including:

As seen in Fig. 3 the users are able to do a translating process to the vocabularies by putting the words of the Anggah-Ungguhing Balinese language or Indonesia language and by clicking the button of Translate. To do the translating process, it must be firstly ascertained that the mobile phone has been connected to internet.

The translation results from the vocabularies can be seen in Figure 4. For instance, the word translated was "Kaki" (leg), the translation result in Indonesia language was Kaki, Kruna Alus Singgih was "cokor", Kruna Alus Sor was "buntut ", and Kruna Andap =" Batis ". 


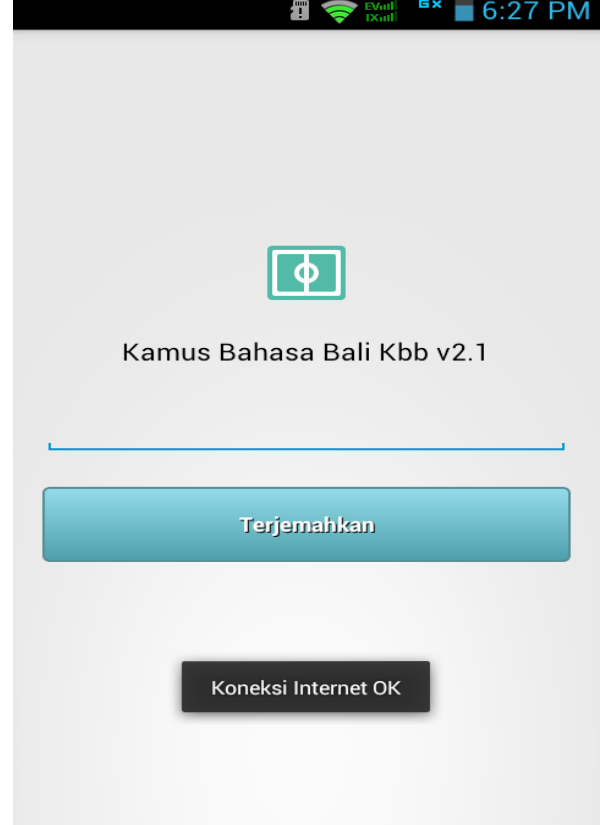

Fig. 3. Translation form

\begin{tabular}{l}
\hline Hasil Terjemahan \\
\hline Bahasa Indonesia-->kaki, \\
Kruna Alus Madia (Ama)-->, \\
Kruna Alus Singgih-->cokor, \\
Kruna Alus Sor-->buntut, \\
Kruna Alus Mider-->, \\
Kruna Mider-->, \\
Kruna Kasar-->, \\
Kruna Andap-->Batis, \\
oK \\
\end{tabular}

Fig. 4. Form of translation results. 


\subsection{Web-based dictionary application}

The web-based application used by the admin to manage the words of AnggahUngguhing Balinese language into Indonesia Language or vice versa. There are some processes that have been conducted in this research:

Figure 5 presents a display of main menu for an administrator. In this menu, there are some features used by administrator to manage the Anggah - Ungguhing Balinese language such as the types of words and Unggah-Ungguhing Balinese language.

Figure 6 shows the process of managing the data of word types, and menu was used by administrator to manage the word types (Indonesia, Kruna alus singgih, Kruna alus madia, Kruna alus sor, Kruna alus mider, Kruna mider, Kruna andap, Kruna kasar).

Figure 7 shows the word types used by the administrator in managing the data of the Anggah-Ungguhing Balinese language. The administrator is able to process the input of words, edit or delete the words in accordance with the word types existing in the database.

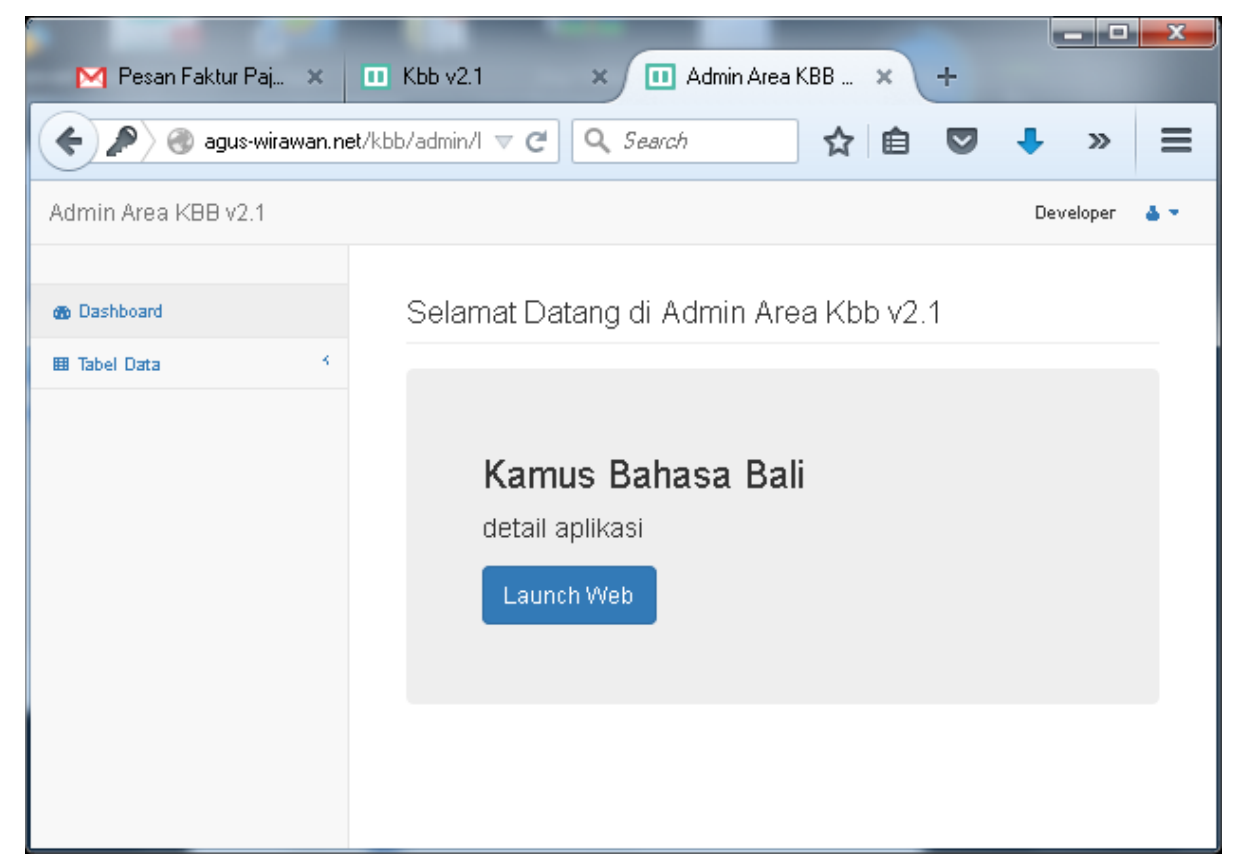

Fig. 5. Main form. 
Paper-The Development of an Android-Based Anggah-Ungguhing Balinese Language Dictionary

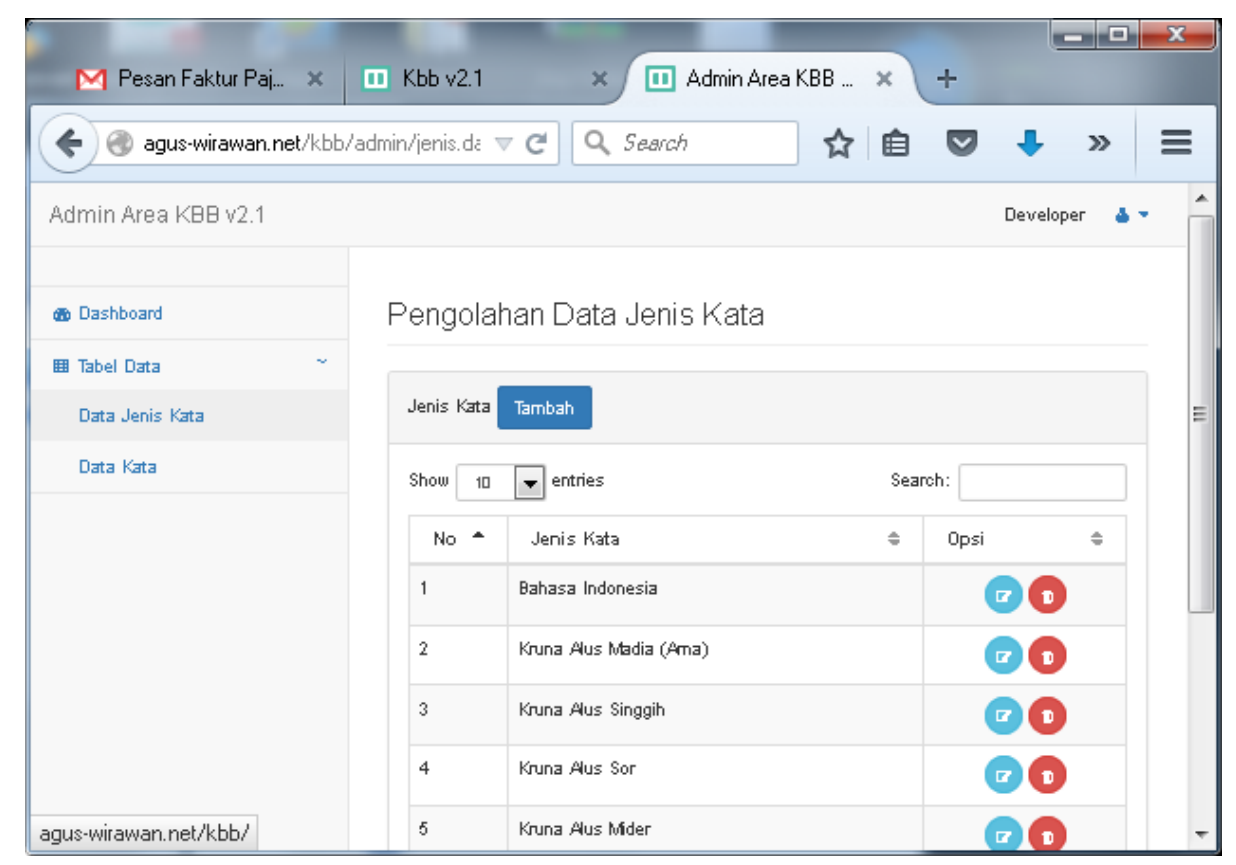

Fig. 6. Form for manages data of word types.

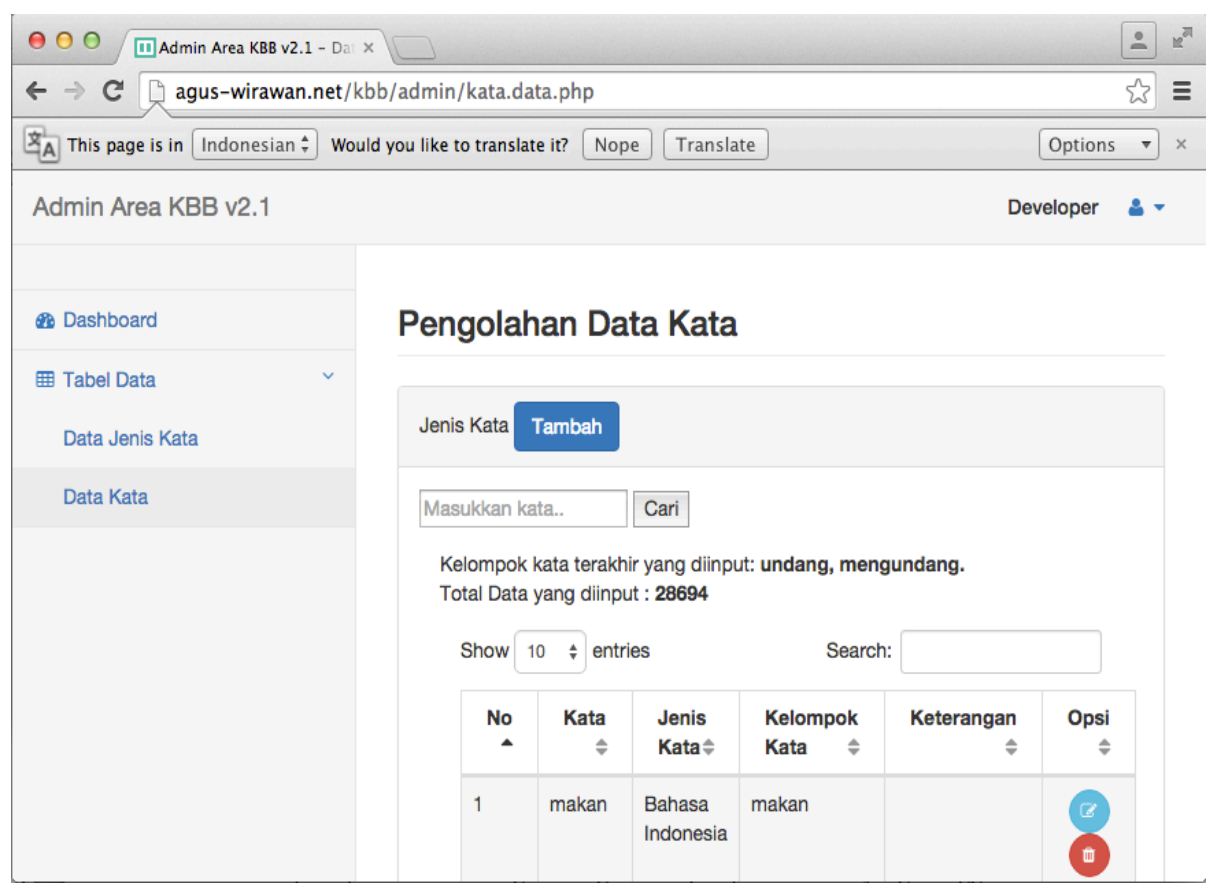

Fig. 7. Form for managing the data of Anggah-Ungguhing Balinese language. 


\subsection{Testing}

This research involved three testing phases including:

1. Testing on technique (technical testing) was conducted by the application developer to test the functionality of application (Black Box Testing) and to check the structure of software algorithm (White Box Testing). The process of this testing was conducted during the software development process. The testing process was based upon the White Box Testing and Black Box Testing. The results on White Box Testing and Black Box Testing conducted by the developer were stated successful and compatible with the need analysis of the system.

2. The test on software as a learning media conducted through the test by experts in media aspect and test by expert in content.

(a) The test on application conducted by the experts in media was performed in $1^{\text {st }}$ July 2015. From the result of test, there were some points needed to be revised related to the inaccuracy of image and incompatibility of image with the material content.

(b) The test on the software by the expert regarding the content was conducted in $2^{\text {nd }}$ July 2015 in which the elements of content eligibility were still inaccurate in this case in the inaccuracy of the selected font type.

(c) In the first test by the expert in media, there were some weaknesses to be revised. For this, the second phase of test was conducted in $5^{\text {th }}$ July 2015 . The test result at the second phase stated that the application of the Anggah-Ungguhing Balinese language dictionary as a learning media has been declared compatible.

(d) In the first test with the content experts, there were a number of weaknesses to be revised; thus, the second phase of this test was conducted in 5 July 2015. The test result stated that the application of the Anggah-Ungguhing Balinese language dictionary from the content of learning was declared compatible.

3. The field test was conducted by means of the test on the students in Department of Balinese Language Education, Universitas Pendidikan Ganesha, taking the speaking subject. The test was conducted from 9 July to 10 July 2015. This test was used to obtain the response of the students taking the speaking subject. The result of the response of the students consisting of 10 declarations was then measured using Likert Scale of Likert 1-5. The highest ideal score and the lowest one were found at 50 and 10 respectively. The measurement of ideal mean and deviation standard was presented as follows:

$$
\begin{aligned}
& \text { Mean ideal }=1 / 2(\text { the highest ideal score }+ \text { the lowest ideal score) } \\
& =1 / 2(50+10) \\
& =30
\end{aligned}
$$

The ideal deviation standard $=1 / 6$ (the highest ideal score - the lowest ideal score)

$$
\begin{aligned}
& =1 / 6(50-10) \\
& =6.7
\end{aligned}
$$

The responses of the students using the android-based dictionary of Anggah Ungguhing Balinese language in speaking subject showed that 20 students stated it 
very positive $(66,67 \%), 8$ students stated positive $(26,67 \%)$ and 2 students were doubtful $(6.67 \%)$. Thus, it can be explained that on average the students were in the category of very positive $(67,7 \%)$ and positive $(23,3 \%)$. This was because they were very interested and felt much helped by the use of this application in following the lecture - particularly in speaking. However, 2 students were doubtful to use this application because having no android smartphone. The distribution of response of the students using the Balinese language dictionary and android is presented in the graph.

\subsection{Discussion}

The development of this application used the programming language of android and PHP; while the database used was MySQL. For the connection between the cellular phone and the database application, it needed the web service application using the PHP language. With the development of the dictionary of Anggah - Ungguhing Balinese language, any hindrance faced in the learning process could be settled particularly in speaking subject. The development of android-based dictionary of AnggahUngguhing Balinese language was able to be an alternative media in the learning process anywhere and anytime. The development of the mobile-based application in learning process can support the Go-Green concept in Universitas Pendidikan Ganesha. In the limited test conducted in the classroom, the response of the students using the application of the dictionary of Anggah - Ungguhing Balinese language in the learning process of speaking subject tended to be very positive.

\section{Conclusion}

Based on the research and discussion above, it can be concluded that:

1. The application of android-based dictionary of Anggah - Ungguhing Balinese language is able to model the glossaries of Anggah-Ungguhing Balinese language.

2. The development of android-based dictionary of Anggah-Ungguhing Balinese language was able to be an alternative media in the learning process anywhere and anytime.

3. The response of the students using the android-based dictionary of AnggahUngguhing Balinese language for the learning process of vocabularies of AnggahUngguhing Balinese language was very positive.

Based on the results above, the suggestion can be presented as follows:

1. For further research it is necessary to develop word structure and the sentence level to understand the communication of Balinese language both in the class and in social life with any social strata.

2. For further research it is necessary to develop a database SQLite for the choices that translation can be made offline.

3. For the further research, it can do the experiment from the development in this research; thus, the learning outcome from the students can be identified. 
4. For the further research, it is possible to combine the learning strategy to make the learning process more interactive.

\section{Acknowledgment}

The authors would like to thank the lectures, staffs, and students particularly in Department of Balinese Language Education, and Department of Informatics Technique Education, Universitas Pendidikan Ganesha that have assisted and supported the implementation of this research particularly in the data of student's responses.

\section{$7 \quad$ References}

[1] Bali Post. (2013). Hari Bahasa Ibu, Pengakuan Internasional. Edition of 21 February 2013

[2] UNESCO. (2016, 2 22). http://en.unesco.org/events/. Retrieved 10 14, 2016,

[3] N. M. S. Anggraeni \& N. N. K. Yasa. (2012). E-service quality terhadap kepuasan dan loyalitas pelanggan dalam penggunaan internet banking. Journal of Finance and Banking 16(2), 293-306.

[4] I. M. A. Wirawan. (2011). Development Learning Media for Mobile Phone Based Materials Basic SQL Syntax in Subjects Advanced Database (Case Study on IT Educational Programs Semester III). Proceeding of International Seminar on Technology of Information and Education. Bridging ICT and Education, ISSN 1907-3739, DIN EN ISO 9001:2008, Cert. No.01 100 086042, Faculty of Engineering, Universitas Negeri Padang

[5] I. M. A. Wirawan. (2010). Sistem Pencatatan Perkembangan Pasien Berbasis Mobile Phone. Prosiding Senapati, ISSN 2087-2658, Universitas Pendidikan Ganesha.

[6] I. M. A. Wirawan \& M. S. Gitakarna. (2015). Development of Adaptive Mobile Learning (AML) on Information System Courses. International Journal of Computer Applications, ISSN 2156-5570, Vol 6, No 12.

[7] A. Muharom, R. Cahyana \& H. Bunyamin. (2013). Pengembangan Aplikasi Sunda Berbasis Android Menggunakan Metode Rapid Application Development (RAD)”, Journal of Algorthm, 10 (1), 1-10.

[8] N. Sarumaha. (2013). Aplikasi Kamus Bahasa Ingris-Indonesia-Nias Berbasis Mobile Android dengan Algoritma String Matching. Journal of Pelita Informatika Budi Darma, Vol V, No 1, ISSN: 2301-9425.

[9] N. G. A. M. C. Dewi. (2012). Aplikasi Penerjemah Bahasa Indonesia ke dalam Bahasa Bali dengan Menggunakan Metode Rule Based. Karmapati, Vol 1, No 4, ISSN: 2252-9063.

[10] I. B. U. Naryana. (1983). Anggah-Ungguhing Basa Bali dan Peranannya Sebagai Alat Komunikasi Bagi Masyarakat Suku Bali. Denpasar: Faculty of Letters, Unud.

[11] I. N. Mendra. (2003). Imba Mebebaosan Ngangge Bahasa Bali. Denpsar: Culture Department of Bali Province.

[12] I. B. M. Suasta. (2001). Berpidato dengan Bahasa Bali.Denpasar: Unud.

[13] R. Doneva, N. Kasakliev, and G. Totkov, "Towards mobile university campuses," 2007

[14] J.Traxler. (2009). Learning in a Mobile Age. International Journal of Mobile and Blended Learning, vol. 1, pp.1-12 https://doi.org/10.4018/jmbl.2009010101

[15] Quinn, C. (2001). Get Ready for M-learning. Training and Development, vol. 20, no. 2, pp. 20-21. 
Paper-The Development of an Android-Based Anggah-Ungguhing Balinese Language Dictionary

[16] MoLeNET. (2010). Mobile-learning myths, available at http://web.archive.org/web/20101015234706/http://www.molenet.org.uk/mobilearinprac/ myths. Retrieved 10 14, 2016

[17] L.Naismith, P. Lonsdale, G. Vavoula, M. Sharples. (2004). Literature Review in Mobile Technologies and Learning, Bristol: NESTA FutureLab.

[18] A. Jones, K. Issroff, E. Scanlon, G. Clough, G., P. Mcandrew. (2006). Using mobile devices for learning in Informal Settings: Is it motivating? In Proceedings of IADIS International conference Mobile Learning, July 14-16.

[19] N. Winters. (2006). What is mobile learning?. In M. Sharples (Ed), Big Issues in Mobile Learning (pp. 1-34). Kaleidoscope Network of Excellence, Mobile Learning Initiative, available at http://telearn.noe-kaleidoscope.org/warehouse/Sharples-2006.pdf.

[20] Sugiono. (2012). Metode Penelitian Kuantitatif, Kualitatif dan R \& D, Alfabeta, Bandung.

\section{Authors}

I Made Agus Wirawan is a lecturer in Department of Informatics Engineering Education, Faculty of Engineering and Vocational, Universitas Pendidikan GaneshaIndonesia (e-mail: imade.aguswirawan@undiksha.ac.id).

Ida Bagus Made Ludy Paryatna is a lecturer in Department of Balinese Language Education, Faculty of Languages and Arts, Universitas Pendidikan GaneshaIndonesia (e-mail: ludy.paryatna@undiksha.ac.id).

Article submitted 04 May 2017. Published as resubmitted by the authors 14 July 2017. 